\title{
Transboundary river basins, their hidden realities
}

\author{
Edith Kauffer
}

\section{The RISC Consortium}

A World Family Portrait is a joint project of the Consortium for Comparative Research on Regional Integration and Social Cohesion (RISC) and Regions $\mathcal{E}$ Cohesion. It aims to promote interdisciplinary and cross-cultural communication through images and essays on the different faces of humanity, including, but not limited to, our similarities and our differences, our strengths and our weaknesses, our hopes and our concerns, our legacies and our aspirations, as well as our interactions with each other and our world. This project seeks to establish a dialogue between human experiences, academic reflections and shared ethics, such as mutual respect, the protection of human dignity and solidarity.

Regions $\mathcal{E}$ Cohesion welcomes submissions of photos and short essays for publication in the World Family Portrait section of the journal. The journal has already published photos and texts on themes such as water, poverty, women, borders, political ideology, democratization, development, religious practices, violence, the environment, and more. Interested contributors should go to the World Family Portrait link at www.risc.lu where texts and photographs can be uploaded along with basic information such as contributor name(s), correspondence address, institutional affiliation and current position. Essays should be approximately 500 words in length. Images should be submitted in a JPEG format at a resolution of approximately 1900 x 1600 pixels. All materials must be original. All inquiries and submissions related to the project should be sent via the forms on the RISC Consortium web portal. 


\section{In this issue}

Regions $\mathcal{E}$ Cohesion is proud to present two photographs by Edith Kauffer that are related to the journal's special section on transboundary waters and river basins. The section includes three articles with focus on water issues at the border between Mexico and the United States in a context of scarcity, with bilateral agreements eventually contested and relatively tense. At the complete opposite of these realities, the following images show the heterogeneity of transboundary river basins at the Mexican borders, particularly in the case with Guatemala.

The first picture captures the Usumacinta river at sunrise from the Mexican side on the right and the Guatemalan Lacandon Sierra Reserve on the left; the atmosphere seems really quiet and relaxing. The second photo presents the Santo Domingo river located close to the border with Guatemala. Biodiversity is high in this region and human activities seem to be missing in both transboundary and bordering rivers;: nevertheless, the pictures are hiding deep conflicts related to dams and underlying realities, such as the lack of water infrastructures surrounding this water border.

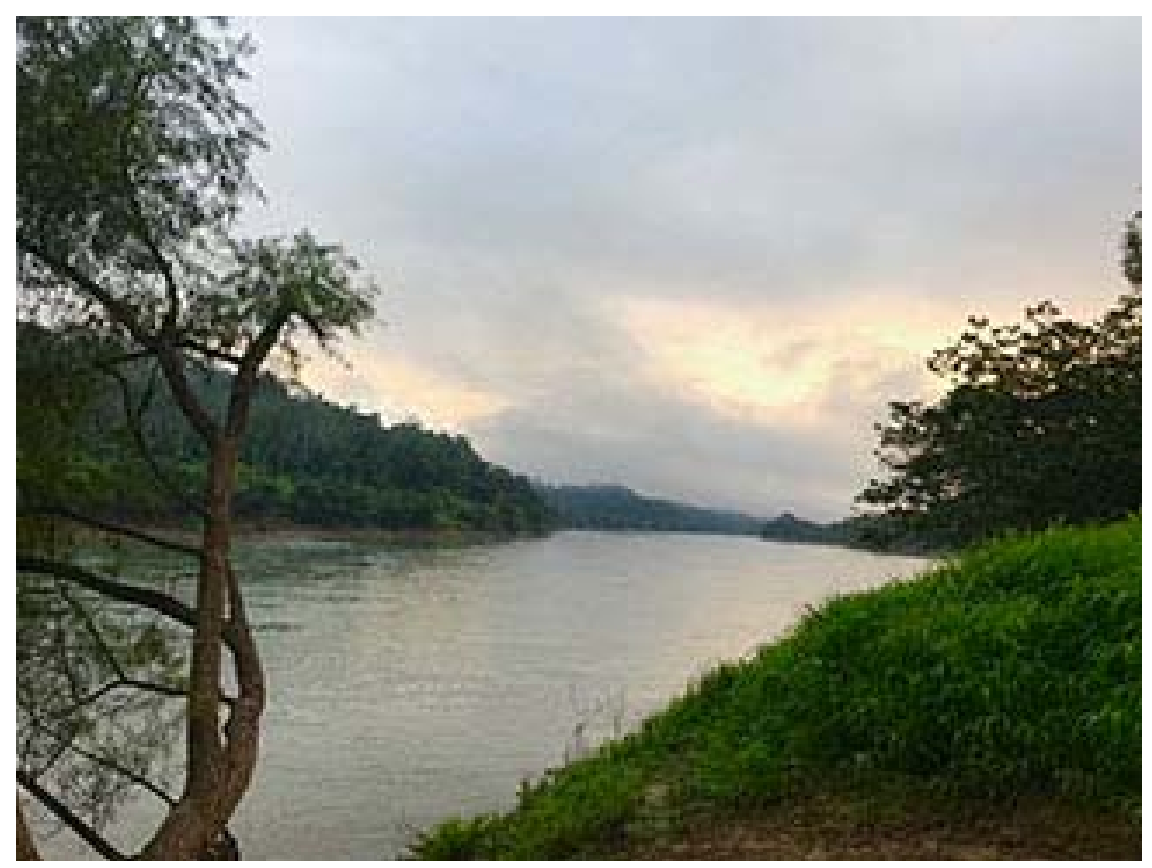

Photo 1 - Edith Kauffer, Usumacinta River 


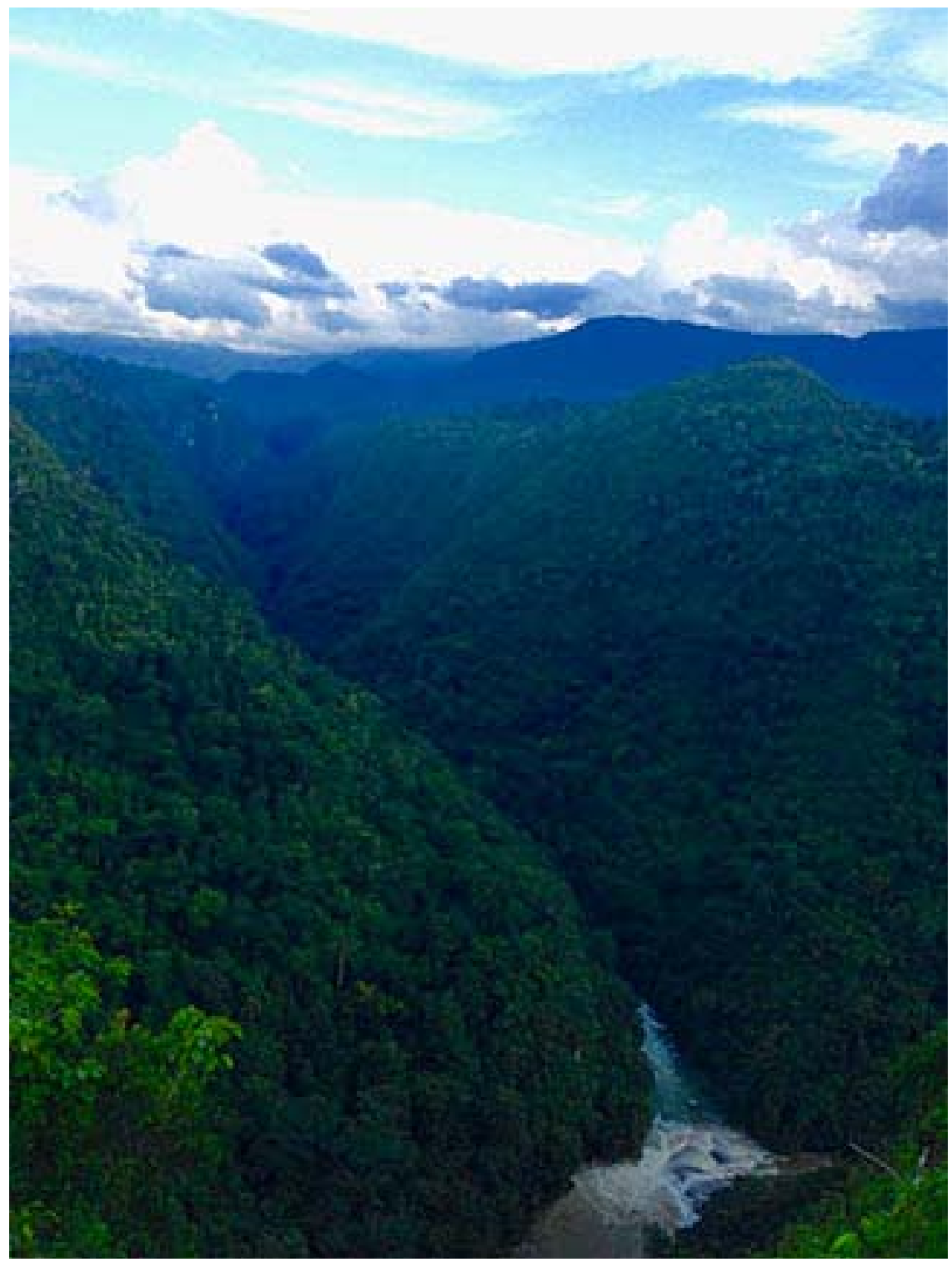

Photo 2 - Edith Kauffer, Santo Domingo River 